\title{
Silver Recovery from Spent Silver Oxide Button Cell by Liquid-Liquid Extraction
}

\author{
Zeferino Gamiño-Arroyo ${ }^{1}{ }^{*}$, Antonio Tapia-Cisneros ${ }^{1}$, Osvaldo M. Zamacona-Saucedo1, \\ Irene Cano-Rodríguez ${ }^{1}$, Alberto F. Aguilera-Alvarado' ${ }^{1}$, Lorena E. Sánchez-Cadena ${ }^{2}$, \\ Fernando I. Gómez-Castro ${ }^{1}$ \\ ${ }^{1}$ Departamento de Ingeniería Química, Universidad de Guanajuato, Guanajuato, México \\ ${ }^{2}$ Departamento de Ingeniería Civil, Universidad de Guanajuato, Guanajuato, México \\ Email: "gaminoz@ugto.mx
}

Received 3 May 2015; accepted 9 July 2015; published 16 July 2015

\begin{abstract}
Button cell batteries are used in clocks, thermometers, remote controls, toys and other devices, and they are usually discarded in the trash once its useful life is over. Some models of these batteries contain silver oxide. In this paper we propose liquid-liquid extraction as separation process to recover the metal. First, silver determination is performed in different models of these batteries and leaching with nitric acid is carried out. Affinity study is done between several commercial extractants for silver. The best performing extractant is the bis(2-ethylhexyl) dithiophosphoric acid (D2EHDTPA). Furthermore, a study of the extraction yields as a function of extractant concentration and time is performed. The distribution isotherm is determined; complex extracted in organic phase and stripping conditions have been identified. With the aim of obtaining industrial application, a number of steps for a countercurrent process were defined by the McCabe-Thiele method. Finally, a study was done in micropilot scale. The results show that it is possible to recover silver from this type of waste.
\end{abstract}

\section{Keywords}

Silver, Spent Button Cells, Leaching, Recovery

\section{Introduction}

The batteries and cells are storing devices of electrochemical energy which as released like electricity when supplies an external circuit. Depending on how long the charge lasts the cells are classified in primary and secondary, the primary are based on an irreversible chemical reaction, therefore cannot be recharged and have only one life cycle. The secondary cells perform a reversible chemical reaction, therefore can be recharged, and their active components are regenerated supplying electrical current in the opposite way to discharge. The battery has one single cell and in some cases have several cells interconnected. The used batteries can be seen like side product of many electronic and portable devices. The batteries can be classified according to the technology they use, their presentation and applications. Such classification is listed on Table 1 [1].

\footnotetext{
${ }^{*}$ Corresponding author.
} 
Table 1. Classification and types of primary and secondary batteries.

\begin{tabular}{|c|c|c|}
\hline \multirow{2}{*}{ Technology } & \multicolumn{2}{|c|}{ Primary batteries (disposable) } \\
\hline & Туре & Uses \\
\hline $\begin{array}{l}\text { Zinc-carbon }\left(\mathrm{Zn} / \mathrm{MnO}_{2}\right) \\
\text { Alkaline }\left(\mathrm{MnO}_{2}\right)\end{array}$ & $\begin{array}{l}\text { AA, AAA, C, D, 9V, 6V, button } \\
\text { (several sizes) More table copy }{ }^{\mathrm{a}}\end{array}$ & Radios, toys, lamps, watches \\
\hline $\begin{array}{c}\text { Mercury oxide }(\mathrm{Zn} / \mathrm{HgO}) \\
\text { Zinc-Air }\left(\mathrm{Zn} / \mathrm{O}_{2}\right) \\
\text { Silver oxide }(\mathrm{Zn} / \mathrm{Ag} 2 \mathrm{O})\end{array}$ & Button (several sizes) & $\begin{array}{c}\text { Video devices and cameras, hearing devices, alarm systems, } \\
\text { watches }\end{array}$ \\
\hline \multirow[t]{2}{*}{ Lithium $\left(\mathrm{Li} / \mathrm{FeS}_{2}, \mathrm{Li} / \mathrm{MnO}_{2}\right)$} & AA, AAA, C, D, 9V, button (several sizes) & Watches, calculators, measuring devices \\
\hline & \multicolumn{2}{|c|}{ Secondary batteries (rechargeable) } \\
\hline $\begin{array}{l}\text { Nickel-cadmium }(\mathrm{NiCd}) \\
\text { Nickel-metal hydride }\end{array}$ & AA, AAA, C, D. & Portable tooling, mobile phones, cameras \\
\hline Lithium-ion (Li-ion) & Several & Mobile phones, computers, video cameras \\
\hline Lead & Lead-acid (automotive batteries) & $\begin{array}{l}\text { Automotive batteries, mowers, wheel chairs, bicycles, } \\
\text { toy cars, tooling, tele-communication systems }\end{array}$ \\
\hline
\end{tabular}

From Table 1, it is noticed that many of these batteries contain heavy metals and that the presence of these in the environment can cause severe pollution problems [2]. On the other hand, in the last years their content has been modified with the purpose to replace or remove them. For example, since 1990 the commercialization of mercury oxide button batteries is forbidden in the USA and Canada. However, in Mexico there is no regulation for the maximum mercury and cadmium contents in these batteries, on the other hand there are no studies about the impact of these contaminants in the environment [3]. Research studies have been focused on leaching [4] [5], several have focused on silver and mercury recovering by precipitation [6] [7]. However, few studies have focused on silver recovery by liquid-liquid extraction.

\section{Methodology}

\subsection{Materials and Extractants}

In order to obtain the aqueous phase button type batteries were leached: Sony SR626SW with nitric acid (1 $\mathrm{mol} / \mathrm{L})$ at ambient temperature $\left(22^{\circ} \mathrm{C} \pm 1^{\circ} \mathrm{C}\right)$. The selected extractants are: triisobutylphosphine sulfide (CYANEX 471X) [8] [9] and the bis (2-ethylhexyl) dithiophosphoric acid (D2EHDTPA) [10]. Table 2 shows the formulas and properties of these extractants. The organic phase is prepared diluting the extractant in kerosene.

\subsection{Experimental Procedure and Extraction Yield}

For the extraction equal volumes $(10 \mathrm{~mL})$ of each phase are in contact during 30 minutes at ambient temperature with constant magnetic stirring, varying concentration of the different selected extractants. At the end of the stirring the phases are divided, the aqueous phase is analyzed by atomic adsorption spectroscopy (AAnalyst 200, Perkin Elmer) and the organic phase by matter balance. The extraction yield is defined as follows:

$$
\% \text { Extraction }=\left([\mathrm{Ag}]_{\text {org }} /\left([\mathrm{Ag}]_{a q}+[\mathrm{Ag}]_{\text {org }}\right) * 100\right.
$$

where $[\mathrm{Ag}]_{\text {org }}$ is the total concentration of silver in organic phase and $[\mathrm{Ag}]_{a q}$ the total concentration of silver in aqueous phase, with a rate of aqueous phase $(A)$ with regards organic phase $(\mathrm{O})$ of 1 (A/O = 1).

\subsection{Extraction Time}

In order to define the minimum contact time between phases, an extraction with phases ratio $(\mathrm{A} / \mathrm{O}=1)$ is performed at obtained conditions, and in a given time a sample is collected to analyze and obtain the extraction yield with regards time.

\subsection{Isotherms of Extraction and Continuous Process}

To obtain the isotherms, the parameters found by experimental procedures are used at different rates of aqueous 
Table 2. Structures of the extractants to this study and their abbreviations.

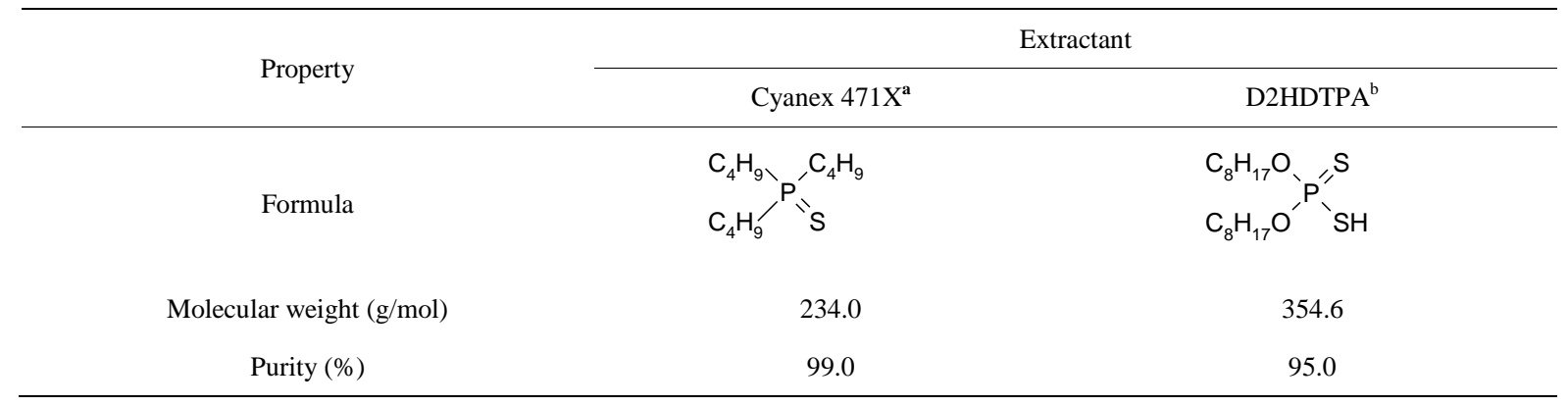

${ }^{\mathrm{a}}$ The extractant CYANEX 471X was supplied by CYTEC Canada Inc. ${ }^{\mathrm{b}}$ The D2EHDTPA has been obtained either by stripping from a commercial zinc salt (Rhein Chemie).

phase in relation to organic phase $(\mathrm{A} / \mathrm{O})$, the concentration of silver in organic phase is calculate as follows:

$$
[\mathrm{Ag}]_{\text {org }}=\mathrm{A} / \mathrm{O}\left([\mathrm{Ag}]_{a q} \text { initial }-[\mathrm{Ag}]_{a q}\right)
$$

where $[\mathrm{Ag}]_{a q \text { initial }}$ is the initial silver concentration before extraction, $[\mathrm{Ag}]_{a q}$ the final silver concentration after extraction, while $\mathrm{A}$ and $\mathrm{O}$ are the volumes of aqueous and organic phases respectively. Aiming for industrial application, the number of stages required for continuous process is computed by using the McCabe-Thiele method [11]. Figure 1 shows the system of mixers-settlers with size of $3.8 \times 23.3 \times 6.5 \mathrm{~cm}$, stirring section of $3.8 \times$ $3.8 \times 6.5 \mathrm{~cm}$. Stirring is made with magnetic stirring and to control flows, pumps and valves are used.

\section{Results and Discussion}

\subsection{Effect of Type of the Extractant}

In the leaching process of battery cells using nitric acid $(1 \mathrm{~mol} / \mathrm{L})$, the concentration of silver is in average 1800 $\mathrm{mg} / \mathrm{L}$, this value is reference to perform the extraction studies. Table 3 lists the extraction yields of each extractant.

\subsection{Effect of Extractant Concentration}

This study allows to select D2HDTPA and an extraction study is performed taking into account the extract concentration with an initial $\mathrm{Ag}$ concentration of $1992 \mathrm{mg} / \mathrm{L}$, ratio $\mathrm{A} / \mathrm{O}=1$, ambient temperature $\left(22^{\circ} \pm 1^{\circ} \mathrm{C}\right)$ and 20 minutes of contact, these results are shown in Figure 2. The concentration of $0.02 \mathrm{~mol} / \mathrm{L}$ of D2EHDTPA is selected, which allows obtaining yield of $80 \%$, in a single extraction stage.

\subsection{Extraction Kinetics}

The kinetic study of extraction is made with an aqueous solution of $60 \mathrm{~mL}$ of silver concentration: $1803 \mathrm{mg} / \mathrm{L}$ in nitric medium $(1 \mathrm{~mol} / \mathrm{L})$ with $60 \mathrm{~mL}$ of an organic solution of extractant $0.02 \mathrm{~mol} / \mathrm{L} .1 \mathrm{~mL}$ of each phase is removed at different times and the concentration is measured by atomic adsorption. Figure 3 shows this study.

From these results it can be considered that balance is achieved at 15 minutes of contact. With these studies the best extraction conditions are found at a concentration of $0.02 \mathrm{~mol} / \mathrm{L}$ of D2EHDTPA and contact time of 15 minutes.

\subsection{Equilibrium of Ag Extraction}

Figure 4 shows the experimental isotherm plotted by the dotted line and the continuous line plots the modeled isotherm.

For an initial concentration of $1743 \mathrm{mg} / \mathrm{L}$ of silver in nitric medium $(1 \mathrm{~mol} / \mathrm{L})$ in the aqueous phase, there are obtained two theoretical extraction stages, with a rate of $\mathrm{A} / \mathrm{O}=0.65$ and a final concentration of silver of 4.7 $\mathrm{mg} / \mathrm{L}$, the calculation of these steps is shown in Figure 5.

In the extraction study in the continuous mixer-settler a flow of $5.7 \mathrm{~mL} / \mathrm{min}$ is used for organic phase and of $3.7 \mathrm{~mL} / \mathrm{min}$ for the aqueous phase $(\mathrm{A} / \mathrm{O} \approx 0.65)$, after 40 minutes, the residual silver concentration in aqueous 


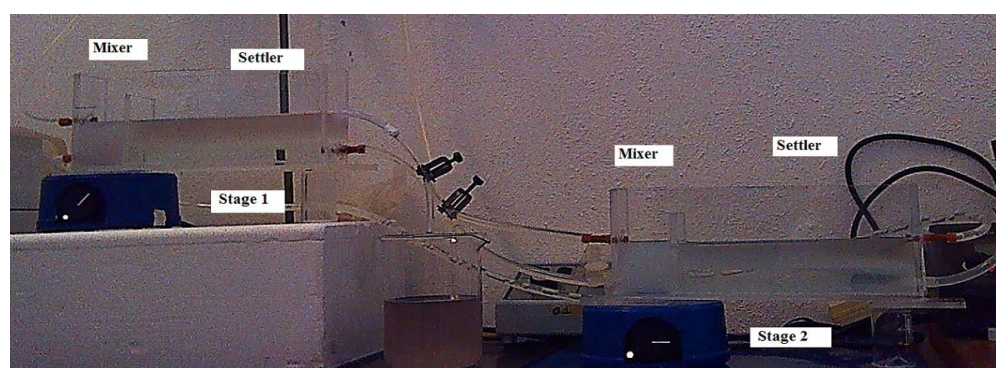

Figure 1. Laboratory mixer-settler (2 stages).

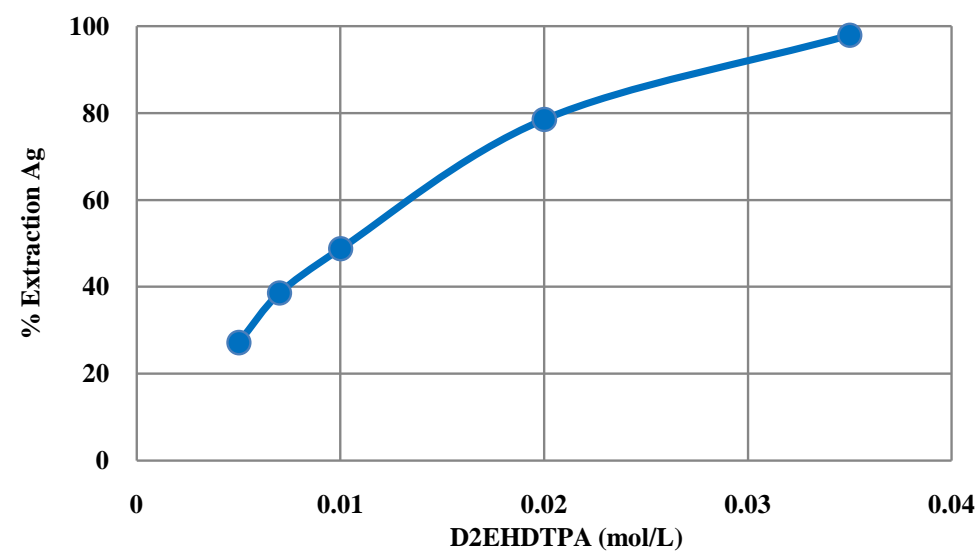

Figure 2. Effect of the extractant concentration on the Ag extraction. Phase ratio $\mathrm{A} / \mathrm{O}=1,22^{\circ} \mathrm{C} \pm 1^{\circ} \mathrm{C}$.

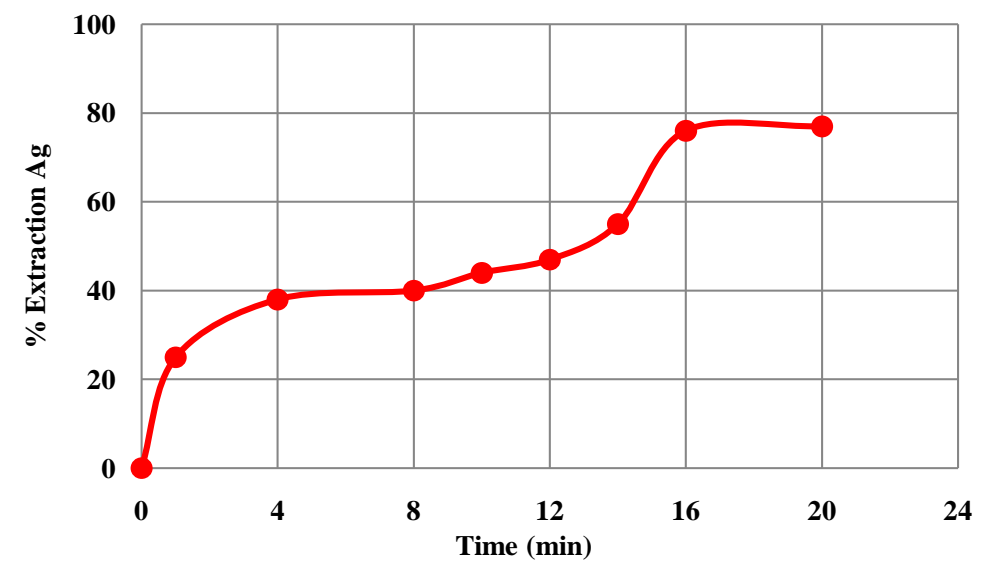

Figure 3. Effect of the extraction time on the Ag extraction. Phase ratio A/O $=1,22^{\circ} \mathrm{C} \pm 1{ }^{\circ} \mathrm{C}$.

Table 3. Extraction of silver with Cyanex $471 \mathrm{X}$ and D2EHDTPA. Phase ratio A/O $=1,22^{\circ} \pm 1^{\circ} \mathrm{C}$.

\begin{tabular}{ccc}
\hline Extractant & Concentration of extractant $(\mathrm{mol} / \mathrm{L})$ & Extraction of $\mathrm{Ag} \%$ \\
\hline D2EHDTPA & 0.1 & 21.1 \\
Cyanex 471X & 0.1 & 100.0 \\
\hline
\end{tabular}

phase is of $17.5 \mathrm{mg} / \mathrm{L}$, a value consistent with the expected value of $4.7 \mathrm{mg} / \mathrm{L}$, obtaining yield of global extraction of 99\%, allowing to validate results obtained by McCabe-Thiele method. For desextraction it is proposed to use thiourea in sulfuric medium at a concentration rate ranging from 0.2 to 0.5 , and contact time of 5 minutes. 


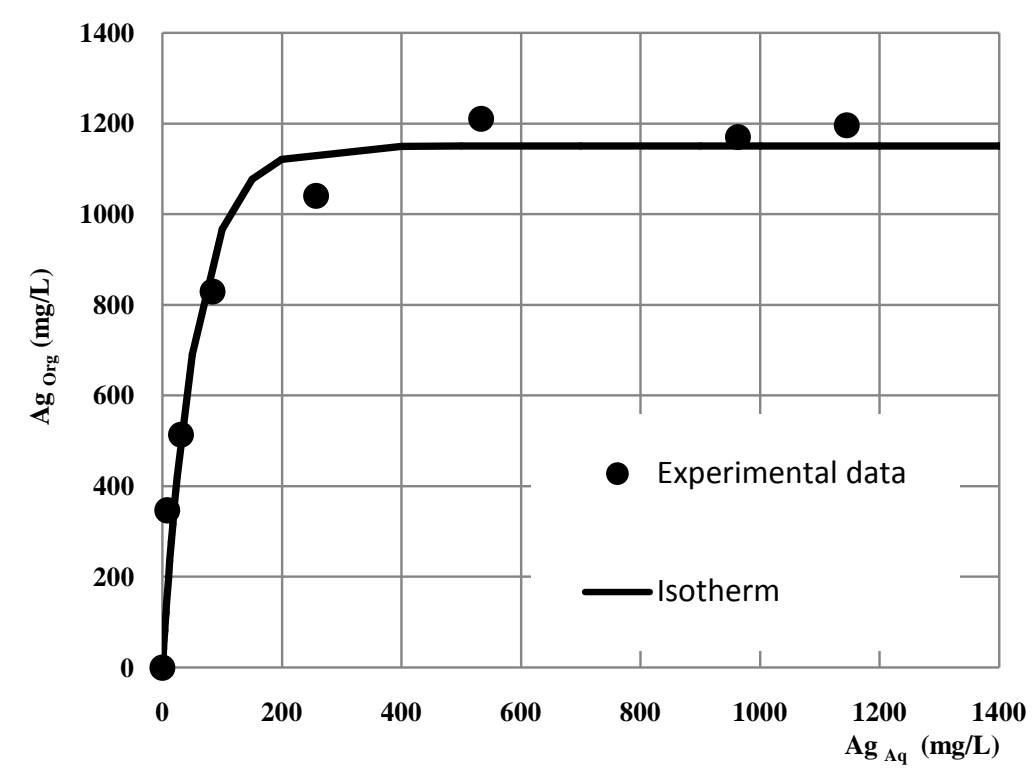

Figure 4. Isoterm of silver extraction. Aqueous phase: Ag initial $1803 \mathrm{mg} / \mathrm{L}$. Organic phase: D2EHDTPA $0.02 \mathrm{~mol} / \mathrm{L}$ time 15 minutes and $22^{\circ} \mathrm{C} \pm 1^{\circ} \mathrm{C}$.

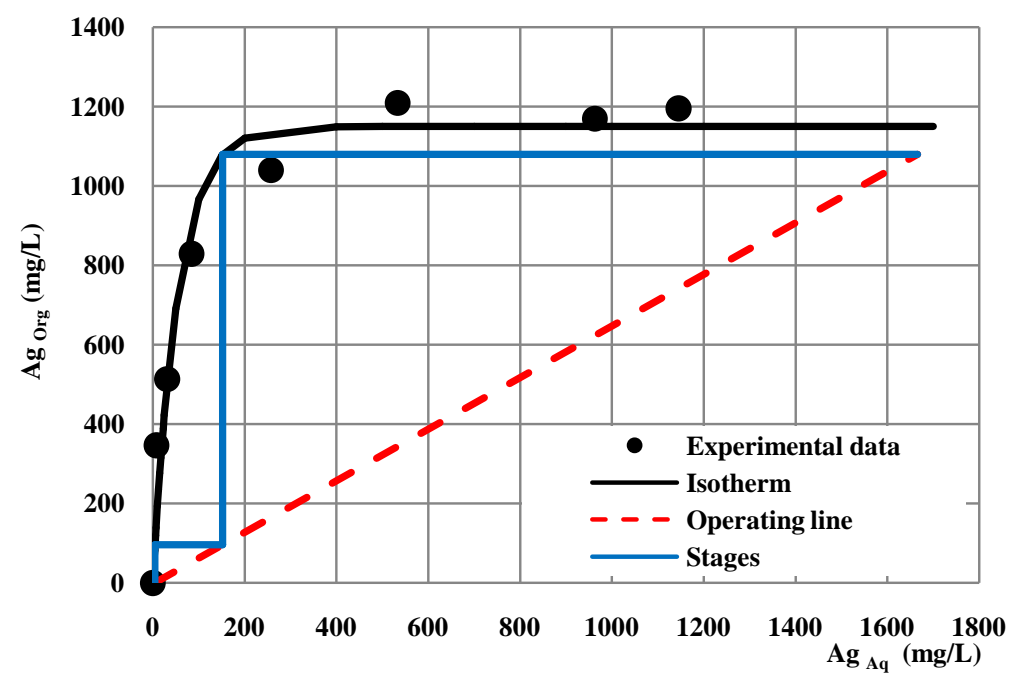

Figure 5. MacCabe-Thiele diagram for the extraction of silver, Ag initial 1743 $\mathrm{mg} / \mathrm{L}$. Organic phase: D2EHDTPA $0.02 \mathrm{~mol} / \mathrm{L}$ time 15 minutes and $22^{\circ} \mathrm{C} \pm 1{ }^{\circ} \mathrm{C}$ $\mathrm{A} / \mathrm{O}=0.65$.

\section{Conclusion}

The D2EHDTPA extractant efficiently recovers silver from nitric acid solutions. The best extraction conditions are at $0.02 \mathrm{~mol} / \mathrm{L}$ concentration, ambient temperature $\left(22^{\circ} \mathrm{C}\right)$, with an extraction time of 15 minutes and $\mathrm{A} / \mathrm{O}=$ 0.65 . The experiments in the continuous mixer-settler, show results that are very similar to those obtained by McCabe-Thiele method. For stripping is found that thiourea at a concentration of $0.5 \mathrm{~mol} / \mathrm{L}$ and duration of 15 minutes. It is necessary to perform studies about stability and number of cycles for which the extractant can be used.

\section{Acknowledgements}

The authors wish to thank to DAIP of Universidad de Guanajuato for the financial support given to this project, 
and to Cytec, Canada Inc., and to Rhein Chemie (Mannheim, Germany) for supplying the extractants.

\section{References}

[1] Gavilán-García, A., Rojas-Bracho L. and Barrera-Cordero, J. (2009) Las pilas en México: Un diagnóstico ambiental. Instituto Nacional de Ecología. SEMARNAT.

http://www2.inecc.gob.mx/publicaciones/consultaPublicacion.html?id_pub=598

[2] Camacho-Aguilar, K.I. (2006) Importancia del Tratamiento de las Pilas Descartadas. Conciencia Tecnológica, 32. http://www.redalyc.org/articulo.oa?id=94403218

[3] Arrieta-Patton, J. and Luján-Pérez, M. (2007) Caracterización de la generación y evaluación de riesgos de las pilas y baterías en desuso en la Ciudad de Cochabamba. Acta Nova, 3, 627-660. http://www.revistasbolivianas.org.bo/pdf/ran/v3n4/v3n4a02.pdf

[4] Sathaiyan, N., Nandakumar, V. and Ramachandran, P. (2006) Hydrometallurgical Recovery of Silver from Waste Silver Oxide Button Cells. Journal of Power Sources, 161, 1463-1468. http://dx.doi.org/10.1016/j.jpowsour.2006.06.011

[5] Aktas, S. (2010) Silver Recovery from Spent Silver Oxide Button Cells. Hydrometallurgy, 104, 106-111. http://dx.doi.org/10.1016/j.hydromet.2010.05.004

[6] Aktas, S. and Morcali, M.H. (2011) Recovery of Mercury from Spent Silver Oxide Button Cells. Minerals \& Metallurgical Processing, 28, 198-203. http://www.smenet.org/docs/publications/mmpj/mmp 201111 198.pdf

[7] Sathaiyan, N. (2014) Reclamation of Mercury from Used Silver Oxide Watch Batteries. ACES, 4, 1-6. http://dx.doi.org/10.4236/aces.2014.41001

[8] Hubicki, Z. and Hubicka, H. (1995) Studies of Extractive Removal of Silver (I) from Nitrate Solutions by Cyanex 471X. Hydrometallurgy, 37, 207-219. http://dx.doi.org/10.1016/0304-386X(94)00027-Z

[9] Tovar-Tovar, R.L., Domínguez-Espinós, O., Gaona-Couto, A., Lobo-Guerrero, A., Palomares-Sánchez, S. and SánchezLoredo, M.G. (2012) A Simple Two-Phase System Involving the Commercial Organophosphorous Extractant Cyanex ${ }^{\circledR 471 x}$ for the Preparation of Silver Sulphide Nanoparticles. MSA, 3, 843-850. http://dx.doi.org/10.4236/msa.2012.312123

[10] Gamino Arroyo, Z., Stambouli, M., Pareau, D., Buch, A., Durand, G. and Avila Rodriguez, M. (2008) Thiosubstituted Organophosphorus Acids as Selective Extractants for $\mathrm{Ag}(\mathrm{I})$ from Acidic Thiourea Solutions. Solvent Extraction and Ion Exchange, 26, 128-144. http://dx.doi.org/10.1080/07366290801904855

[11] McCabe, W.L., Smith, J.C. and Harriot, P. (2001) Unit Operations of Chemical Engineering. 6th Edition, McGraw-Hill International Edition, Singapore. 